\title{
Detection of $\mathrm{PrP}^{\mathrm{Sc}}$ in lung and mammary gland is favored by the presence of Visna/maedi virus lesions in naturally coinfected sheep
}

\author{
Eider Salazar ${ }^{1}$, Eva Monleón ${ }^{2}$, Rosa Bolea ${ }^{2}$, Cristina Acín ${ }^{2}$, Marta Pérez ${ }^{1}$, \\ Neila Álvarez ${ }^{1}$, Iratxe LeginagoikoA ${ }^{3}$, Ramón Juste $^{3}$, Esmeralda Minguijón ${ }^{3}$, \\ Ramsés Reina ${ }^{4}$, Idoia Glaria ${ }^{4}$, Eduardo Berriatua ${ }^{5}$, Damián DE Andrés ${ }^{4}$, \\ Juan José BAdiola ${ }^{1,2}$, Beatriz Amorena ${ }^{4}$, Lluís LujÁN ${ }^{1 *}$ \\ ${ }^{1}$ Department of Animal Pathology, Veterinary Faculty, University of Zaragoza, 177 Miguel Servet street, \\ 50013 Zaragoza, Spain \\ ${ }^{2}$ Research Center on Encephalopaties and Emerging Diseases, University of Zaragoza, 177 Miguel Servet street, \\ 50013 Zaragoza, Spain \\ ${ }^{3}$ Neiker-Tecnalia (Basque Institute for Agricultural Research and Development), 48160 Derio, Spain \\ ${ }^{4}$ Institute of Agrobiotechnology, CSIC-Public University of Navarra-Government of Navarra, Car. Mutilva Baja, \\ 31192 Mutilva Baja, Spain \\ ${ }^{5}$ Enfermedades Parasitarias, Faculdad de Veterinaria, Campus de Espinardo, 30100 Murcia, Spain
}

(Received 8 February 2010; accepted 27 April 2010)

\begin{abstract}
There are few reports on the pathogenesis of scrapie ( $\mathrm{Sc}$ ) and Visna/maedi virus (VMV) coinfections. The aim of this work was to study in vivo as well as post mortem both diseases in 91 sheep. Diagnosis of Sc and VMV infections allowed the distribution of animals into five groups according to the presence $(+)$ or absence (-) of infection by Sc and VMV: Sc-/VMV-, Sc-/VMV+, Sc+/VMV- and Sc+/ $\mathrm{VMV}+$. The latter was divided into two subgroups, with and without VMV-induced lymphoid follicle hyperplasia (LFH), respectively. In both the lung and mammary gland, $\operatorname{PrP}^{\mathrm{Sc}}$ deposits were found in the germinal center of hyperplasic lymphoid follicles in the subgroup of Sc+/VMV+ having VMV-induced LFH. This detection was always associated with (and likely preceded by) $\mathrm{PrP}^{\mathrm{Sc}}$ observation in the corresponding lymph nodes. No $\mathrm{PrP}^{\mathrm{Sc}}$ was found in other VMV-associated lesions. Animals suffering from scrapie had a statistically significantly lower mean age than the scrapie free animals at the time of death, with no apparent VMV influence. ARQ/ARQ genotype was the most abundant among the 91 ewes and the most frequent in scrapie-affected sheep. VMV infection does not seem to influence the scrapie risk group distribution among animals from the five groups established in this work. Altogether, these data indicate that certain VMVinduced lesions can favor $\mathrm{PrP}^{\mathrm{Sc}}$ deposits in Sc non-target organs such as the lung and the mammary gland, making this coinfection an interesting field that warrants further research for a better comprehension of the pathogenesis of both diseases.
\end{abstract}

\section{Visna/maedi / scrapie / sheep / coinfection}

\section{INTRODUCTION}

Scrapie and Visna/maedi (VM) are small ruminant infections that are characterised by a

\footnotetext{
* Corresponding author: Lluis.Lujan@unizar.es
}

long incubation period and that are also classified as slow diseases [46]. The etiology of scrapie is the misfolded isoform of the prion protein $\left(\mathrm{PrP}^{\mathrm{Sc}}\right)$ that derives from the normal cellular isoform of the prion protein $\left(\mathrm{PrP}^{\mathrm{C}}\right)$ [39], whereas VM is caused by a lentivirus called

This is an Open Access article distributed under the terms of the Creative Commons Attribution-Noncommercial License (http://creativecommons.org/licenses/by-nc/3.0/), which permits unrestricted use, distribution, and reproduction in any noncommercial medium, provided the original work is properly cited. 
Visna/maedi virus (VMV) [17] that is similar to other lentiviruses such as the human immunodeficiency virus [12]. Scrapie is a neurodegenerative disease that belongs to the group of Transmissible Spongiform Encephalopathies (TSE) like Bovine Spongiform Encephalopathy (BSE) and the variant of Creutzfeldt Jakob disease (vCJD). Scrapie mainly causes neuronal vacuolation and gliosis of the central nervous system (CNS) due to the deposition of $\mathrm{PrP}^{\mathrm{Sc}}$ [18]. However $\operatorname{PrP}^{\mathrm{Sc}}$ can also be found in the lymphoreticular system (LRS) prior to the accumulation in the CNS. Apparently, $\operatorname{PrP}^{\mathrm{Sc}}$ does not cause lesions in this system [19]. VM affects mainly the lungs [45], mammary gland [35], CNS [47] and joints [9], with the most characteristic lesions being interstitial pneumonia (IP) and lymphoid follicle hyperplasia (LFH) in the lungs [34], interstitial mastitis [10], non suppurative encephalomyelitis and leukoencephalomalacia [8] and proliferative arthritis [9]. At the moment there is neither treatment nor vaccine for these two diseases.

Scrapie and VM are both endemic diseases in Spain. Scrapie was first diagnosed in 1987 [14] and since the implementation of the active and passive surveillance systems in 2001, 170 outbreaks were detected until 2006, and about 527 positive animals have been diagnosed out of 390941 animals tested ${ }^{1}$. VMV was first reported in Spain in 1984 [15] and studies on seroprevalence have demonstrated a variable level of infection that in certain locations includes almost all flocks and up to $50 \%$ of individuals [38].

$\operatorname{PrP}^{\mathrm{C}}$ is widely distributed throughout ovine tissues [21] and its concentration in the lungs and mammary gland is about 20 and 90 -fold less compared with that in the brain [33], while $\mathrm{PrP}^{\mathrm{Sc}}$ is mostly located in the nervous system and LRS [22, 41]. VMV infection, however, induces

\footnotetext{
${ }^{1}$ Ministerio de medio ambiente y medio rural $\mathrm{y}$ marino (MARM), Ganadería. Sanidad animal, Encefalopatías espongiformes transmisibles de los pequeños rumiantes, Información específica respecto a la tembladera o scrapie en pequeños rumiantes [on line] http://www.mapa.es/es/ganaderia/pags/ sanidad_animal/caprino/carino.htm\#documentos [consulted 20 January 2010].
}

hyperplasia of the LRS in the CNS, lung and mammary gland. It is therefore possible to expect an interaction between $\mathrm{PrP}^{\mathrm{Sc}}$ and VMV at the lymphoid tissue level in scrapie target (CNS) and non-target organs (lungs and mammary gland). Actually, an unexpected/abnormal $\mathrm{PrP}^{\mathrm{Sc}}$ presence associated with chronic inflammations has already been reported either in mice suffering from nephritis, pancreatitis and hepatitis [20] and sheep affected by chronic mastitis induced by VMV infection [6, 25, 27].

The aim of this work was to study the $\mathrm{PrP}^{\mathrm{Sc}}$ presence and possible interaction with VMV in VM target organs (mainly lungs, mammary gland and CNS) in naturally scrapie and VM coinfected sheep.

\section{MATERIALS AND METHODS}

\subsection{Animals and antemortem studies}

A total of 91 Rasa Aragonesa ewes, ranging in age from 1 to 13 years and belonging to the experimental flock from the University of Zaragoza were used in this study [32]. Scrapie was diagnosed in vivo by immunohistochemical analysis for $\mathrm{PrP}^{\mathrm{Sc}}$ detection in lymphoid tissue from biopsies of the 3rd eyelid [36] or rectum [16] using mAb L42 antibody (R-Biopharm, Darmstadt, Germany; 1:500) according to previously-described methods [52]. Infection by VMV was diagnosed by serum antibody detection using a recombinant protein based ELISA (ELITEST $^{\mathrm{m}}$, Hyphen Biomed, Neuville sur Oise, France) [42]. The animals were clinically examined for scrapie and VM through periodic examinations for the presence of clinical signs related to both infections $[35,45,51]$. Genotype analysis for scrapierelated codons $(136,154,171)$ was performed [1] and genotypes were assigned to risk groups predefined by the National Scrapie Plan [11].

\subsection{Postmortem diagnosis, pathological and PCR studies}

Scrapie infected animals were killed at the end stage of the disease when showing terminal clinical signs such as extreme ataxia, tremors and/or pruritus. VMV infected animals were culled if respiratory distress and/or cachexia were observed. Four sheep in the preclinical status were put down due to unrelated diseases such as bacterial pneumonia and pregnancy 
Table I. Number of sheep and mean age in each group. Percentage of animals in brackets.

\begin{tabular}{|c|c|c|c|c|c|c|}
\hline \multirow[t]{2}{*}{ Group } & \multirow[t]{2}{*}{$\mathrm{Sc}^{1}-/ \mathrm{VM}^{2}-$} & \multirow[t]{2}{*}{$\mathrm{Sc}-/ \mathrm{VM}+$} & \multirow[t]{2}{*}{$\mathrm{Sc}+/ \mathrm{VM}-$} & \multicolumn{2}{|c|}{$\mathrm{Sc}+/ \mathrm{VM}+$} & \multirow[t]{2}{*}{ Total } \\
\hline & & & & $\begin{array}{l}\text { With VMV- } \\
\text { associated LFH }\end{array}$ & $\begin{array}{l}\text { Without VMV- } \\
\text { associated LFH }\end{array}$ & \\
\hline$n$ & $10(10.9)$ & $26(28.6)$ & $30(33.0)$ & $14(15.4)$ & $11(12.1)$ & $91(100)$ \\
\hline Mean age (years) & 8.50 & 7.46 & 4.23 & 5 & 5.18 & 5.85 \\
\hline
\end{tabular}

toxemia. Sheep were given an intravenous barbiturate overdose (Dolethal, Vetoquinol S.A., Lure, France) and exsanguinated.

Samples from all tissues including mammary gland, lung, CNS, mediastinal and mammary lymph node were fixed in $10 \%$ formalin for histopathological processing. Samples from the same tissues were also stored at $-80{ }^{\circ} \mathrm{C}$ for scrapie rapid tests and VMV PCR evaluation. Scrapie confirmation was performed by immunohistochemical detection of $\operatorname{PrP}^{\mathrm{Sc}}$ in CNS and lymphoid tissues following previously-described methods $[2,32]$. A subjective assessment of the intensities of $\mathrm{PrP}^{\mathrm{Sc}}$ signals obtained by immunohistochemistry (IHC) in the CNS and lymphoid tissue in all coinfected animals $(\mathrm{Sc}+/ \mathrm{VM}+)$ was performed. The $\mathrm{PrP}^{\mathrm{Sc}}$ intensity was classified from - to +++ following previously-described scores [5, 49].

The presence of VMV-related lesions in target organs $[8,30]$ was studied in all 91 ewes and they were only found in the lungs and mammary gland but not in the CNS. Scoring of histological VMV-related lesions in the lungs and mammary gland was performed on all coinfected animals. The parameters scored were the presence of IP (presence of fibrosis, mononuclear cell infiltration and smooth muscle hyperplasia), LFH (+: $<2$ follicles; ++: 3-6 follicles; +++ : $>6$ follicles per $40 \times$ field) and bronchial epithelisation. VMV infection was verified only in the coinfected group by PCR amplification of LTR (300 nt) and gag (490 nt) regions of the VMV genome using previously described primers and conditions [40]. For amplification, genomic DNA was extracted from tissue samples (mammary gland and lungs) with a QIAamp ${ }^{\circledR}$ DNA Blood Mini Kit (Qiagen, Hilden, Germany).

An animal was finally classified as scrapie positive $(\mathrm{Sc}+)$ if $\mathrm{PrP}^{\mathrm{Sc}}$ was detected immunohistochemically in the CNS and/or LRS, whereas an animal was classified as VMV positive (VMV+) if the animal was seropositive for ELITEST ${ }^{\mathrm{m}}$. On the basis of the results obtained, 5 groups were defined: Double negative $(\mathrm{Sc}-/ \mathrm{VM}-)$, VMV positive only $(\mathrm{VM}+)$, scrapie positive only $(\mathrm{Sc}+)$ and double positive $(\mathrm{Sc}+/$ $\mathrm{VM}+$ ). The $\mathrm{Sc}+/ \mathrm{VM}+$ animals were subdivided into two further groups depending on the presence or absence of LFH induced by VMV in the lungs and/ or mammary gland (Tab. I).

\subsection{Additional tests in the lungs and mammary gland}

In order to prove the presence of $\operatorname{PrP}^{\mathrm{Sc}}$ in the lungs and mammary gland, four additional tests were performed to the $14 \mathrm{VMV}$-scrapie double positive sheep showing LFH and in 3 ARQ/ARQ sheep from each of the other four groups (Tab. II): (1) IHC for $\mathrm{PrP}^{\mathrm{Sc}}$ detection, as applied in the CNS and LRS [2, 32], (2) Western blotting (WB; Prionics ${ }^{\circledR}$-Check WESTERN SR, Zurich-Schlieren, Prionics AG, Switzerland) using mAb P4 as the primary antibody (R-Biopharm, Darmstadt Germany; 1:2500) [5], processing the sample as described for retropharyngeal lymph node [26] and (3) two ELISA tests (BioRad $\mathrm{TeSeE}^{\mathrm{m} \mathrm{s}}$ sheep/goat, Hercules, CA, USA, and IDEXX HerdCheck $^{\mathrm{TM}}$, Westbrook, ME, USA). For these ELISA, an amount of 350 and $300 \mathrm{mg}$ respectively were taken from the lungs and mammary gland. Tissues were homogenised using kit gridding tubes and 4 or 5 agitation cycles in both ELISA until the tissue was correctly homogenised. For BioRad ELISA, the procedure followed the manufacturer's instructions and for the IDEXX ELISA, the "Standard protocol" (as per kit definition) was selected. Based on the results of these four tests, a "Final Result" was established: a sample was negative if all four tests were negative but a sample was considered positive if IHC and/or WB were positive, since they are the reference standard techniques for the World Organisation for Animal Health (OIE). 
Table II. VM and scrapie detection in the lung and mammary gland in $\mathrm{Sc}+\mathrm{VM}+$ infected sheep.

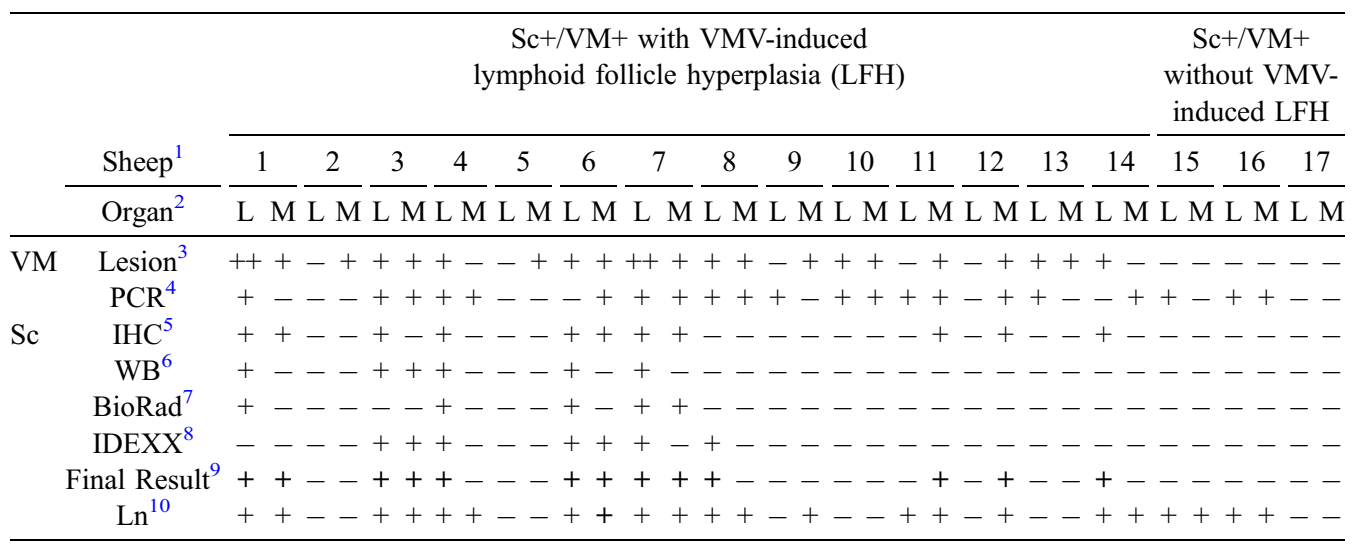

${ }^{1}$ All animals were positive for detection of VMV antibodies (ELITEST ${ }^{\mathrm{m}}$, Hyphen Biomed).

${ }^{2}$ Organ: $\mathrm{L}=$ lung, $\mathrm{M}=$ mammary gland.

${ }^{3}$ Lesion: presence of VMV-related LFH.

${ }^{4}$ PCR: detection VMV-LTR sequences.

${ }^{5}$ IHC: detection of $\mathrm{PrP}^{\mathrm{Sc}}$ by immunohistochemistry.

${ }^{6}$ WB: detection of $\operatorname{PrP}^{\mathrm{Sc}}$ by Western blotting (Prionics ${ }^{\circledR}$-Check WESTERN SR, Prionics AG).

${ }^{7}$ BioRad: detection of $\mathrm{PrP}^{\mathrm{Sc}}$ by BioRad ELISA (BioRad TeSeE ${ }^{\mathrm{mi}}$ sheep/goat).

${ }^{8}$ IDEXX: detection of $\operatorname{PrP}^{\mathrm{Sc}}$ by IDEXX ELISA (IDEXX HerdCheck ${ }^{\mathrm{mi}}$ ).

${ }^{9}$ Final Result: negative (-): all techniques for $\mathrm{PrP}^{\mathrm{Sc}}$ detection were negative; Positive (+): IHC and/or WB were positive.

${ }^{10} \mathrm{Ln}$ : IHC for $\mathrm{PrP}^{\mathrm{Sc}}$ in the associated lymph node (l: mediastinal lymph node, m: mammary lymph node).

\subsection{Statistical analysis}

In order to detect differences in the mean age between groups $(n=5)$, an analysis using the Duncan test was performed. The four animals killed in the preclinical status were not included in this study.

\section{RESULTS}

\subsection{Scrapie and VM status}

Final classification of sheep was achieved only after the post-mortem analysis and the animals were classified into 5 groups (Tab. I). Regarding in vivo diagnosis, 41 out of 55 scrapie positive animals $(74.5 \%)$ were detected by the 3rd eyelid and/or rectal biopsies.

All the scrapie positive sheep (Sc+/VMVand $\mathrm{Sc}+\mathrm{VMV}+$ groups) showed a significantly decreased mean age $(P$ value: $<0.001)$ compared to non-scrapie sheep (Sc-/VMV - and $\mathrm{Sc}-/ \mathrm{VMV}+$ groups), independently of the presence of VMV infection or VM-related lesions. There were no statistically significant differences between the $\mathrm{Sc}+$ groups regarding mean age (Sc+/VMV - and Sc+/VMV+ groups). Furthermore, no differences in $\operatorname{PrP}^{\mathrm{Sc}} \mathrm{IHC}$ staining intensities in CNS and LRS were observed between $\mathrm{Sc}+/ \mathrm{VM}+$ sheep with and without VMV related LFH (data not shown).

VM lesions in the lung and mammary gland consisted of LFH and diffuse interstitial inflammation that involved mononuclear inflammatory cells, such as lymphocytes, macrophages and plasma cells. The lung and mammary gland also presented smooth muscle hyperplasia and fibrosis, respectively. In the $\mathrm{Sc}+\mathrm{VMV}+$ group with VM-induced LFH $(n=14), 2$ animals showed LFH only in the lung (Nos. 4 and 14), 5 only 

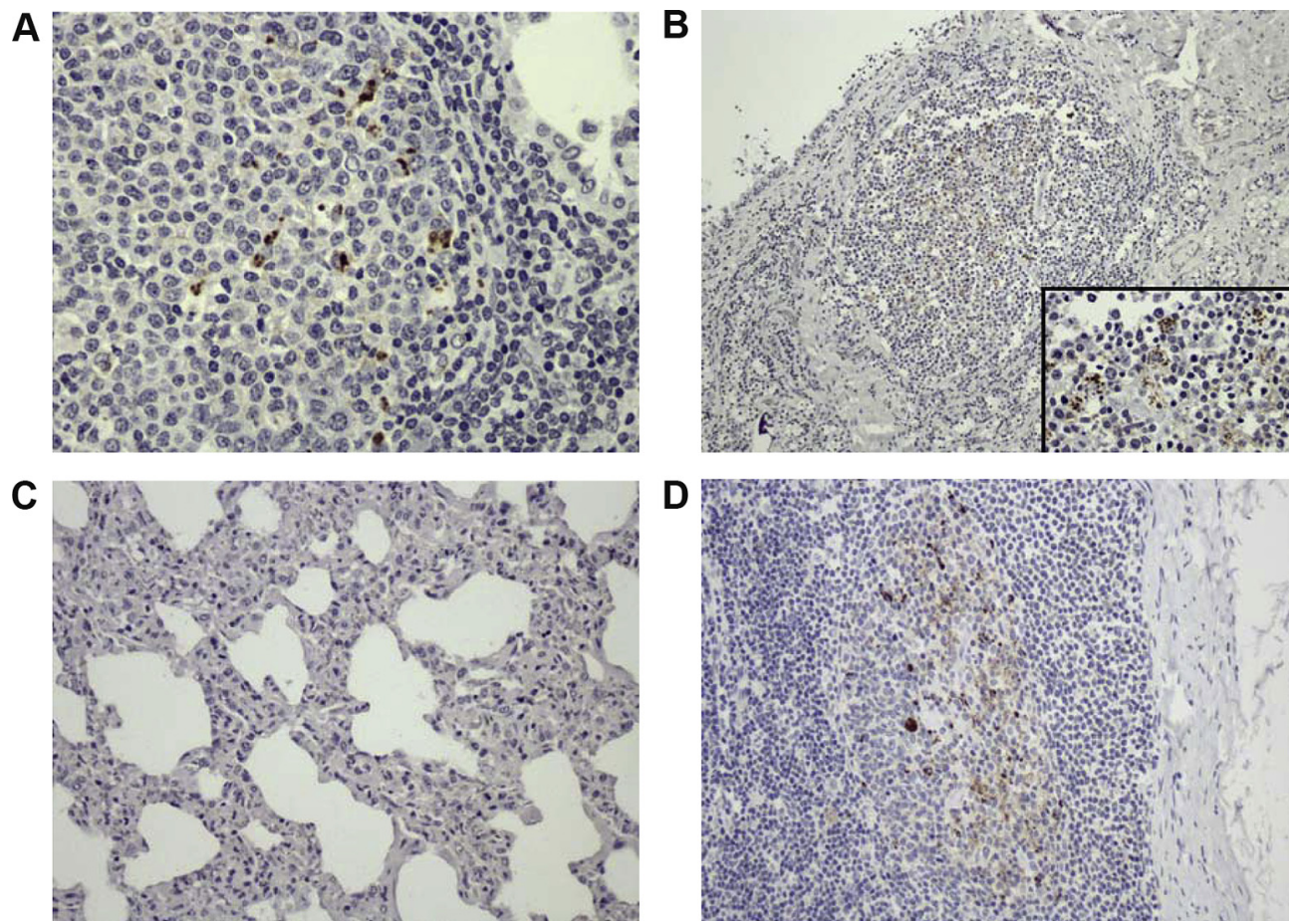

Figure 1. Detection of $\operatorname{PrP}^{\mathrm{Sc}}$ by immunohistochemistry. (A) Lung, scrapie-VM coinfected animal. Scattered $\mathrm{PrP}^{\mathrm{Sc}}$ deposition within the germinal center of a lymphoid follicle close to an alveolar space, $40 \times$. (B) Mammary gland, scrapie-VM coinfected animal. $\mathrm{PrP}^{\mathrm{Sc}}$ deposition within the germinal center of a lymphoid follicle close to a lactiferous duct, 10×. Insert: Detail of the same image, 60×. (C) Lung, scrapieVM coinfected animal. Lack of $\operatorname{PrP}^{\mathrm{Sc}}$ detection within the IP, $20 \times$. (D) Mediastinal lymph node, scrapie$\mathrm{VM}$ coinfected animal. $\mathrm{PrP}^{\mathrm{Sc}}$ presence within the germinal centers, $20 \times$. (A color version of this figure is available at www.vetres.org.)

in the mammary gland (Nos. 2, 5, 9, 11 and 12) and 7 in both organs (Nos. 1, 3, 6, 7, 8, 10 and 13) (Tab. II). The presence of LFH in the lung and mammary gland was always related with the presence of interstitial inflammation. Taken together, among the 28 organs analysed from the $14 \mathrm{Sc}+/ \mathrm{VMV}+$ with $\mathrm{VM}$ induced LFH ewes (14 lungs and 14 mammary glands sampled), 21 showed VM-induced LFH. According to the PCR results, 18 of these organs (9 lungs and 9 mammary glands) were positive for the VMV genome. In the group $\mathrm{Sc}+1$ $\mathrm{VMV}+$ without VM-induced LFH, the lesions consisted of IP only, interstitial mastitis only or both, and 3 of the 6 organs were positive for VMV provirus for VMV in the PCR (Tab. II).
Regarding scrapie, four additional tests were used to detect $\mathrm{PrP}^{\mathrm{Sc}}$ presence in the lung and the mammary gland and the results are detailed in Table II. IHC confirmed the presence of $\mathrm{PrP}^{\mathrm{Sc}}$ in both organs in 3 sheep (Nos. 1, 6 and 7), only in the lung in 3 sheep (Nos. 3, 4 and 14) (Fig. 1A) and only in the mammary gland in 2 sheep (Nos. 11 and 12) (Fig. 1B). WB yielded positive results in both organs in one sheep (No. 3), and only in the lung in 4 sheep (Nos. 1, 4, 6 and 7). BioRad ELISA was positive in both organs in one sheep (No. 7) and only in the lung in 3 sheep (Nos. 1, 4 and 6). Finally, IDEXX ELISA was positive in both organs in 2 sheep (Nos. 3 and 6) and in the lung in 3 sheep (Nos. 4, 7 and 8). 
Table III. Classification of the 91 sheep included in this work per risk group (as defined by the National Scrapie Plan [11]) and scrapie and VM status.

\begin{tabular}{|c|c|c|c|c|c|c|c|}
\hline \multirow{2}{*}{$\begin{array}{l}\text { Risk group } \\
\text { (R) }\end{array}$} & \multirow[t]{2}{*}{ Genotype } & \multirow{2}{*}{$\mathrm{Sc}-/ \mathrm{VM}-$} & \multirow{2}{*}{$\mathrm{Sc}-/ \mathrm{VM}+$} & \multirow{2}{*}{$\mathrm{Sc}+/ \mathrm{VM}-$} & \multicolumn{2}{|c|}{$\mathrm{Sc}+/ \mathrm{VM}+$} & \multirow{2}{*}{ Total } \\
\hline & & & & & $\begin{array}{c}\text { With VMV } \\
\text { LFH }\end{array}$ & $\begin{array}{c}\text { Without VMV } \\
\text { LFH }\end{array}$ & \\
\hline $\mathrm{R} 2$ & ARR/ARQ & 1 & 9 & 0 & 0 & 0 & $10(11)$ \\
\hline R3 & AHQ/ARQ & 2 & 1 & 0 & 0 & 0 & $3(3.3)$ \\
\hline R3 & ARH/ARH & 0 & 1 & 0 & 0 & 0 & $1(1.1)$ \\
\hline R3 & ARH/ARQ & 0 & 4 & 0 & 1 & 1 & $6(6.6)$ \\
\hline R3 & ARQ/ARQ & 7 & 8 & 24 & 13 & 9 & $61(67)$ \\
\hline R4 & ARR/VRQ & 0 & 1 & 0 & 0 & 0 & $1(1.1)$ \\
\hline R5 & ARQ/VRQ & 0 & 2 & 4 & 0 & 1 & $7(7.7)$ \\
\hline R5 & VRQ/VRQ & 0 & 0 & 2 & 0 & 0 & $2(2.2)$ \\
\hline Total & & $10(10.9)$ & $26(28.6)$ & $30(33.0)$ & $14(15.4)$ & $11(12.1)$ & $91(100.00)$ \\
\hline
\end{tabular}

The "Final Result" showed that 4 sheep were positive for $\mathrm{PrP}^{\mathrm{Sc}}$ in both organs (Nos. 1, 3, 6 and 7), 3 ewes were positive for $\mathrm{PrP}^{\mathrm{Sc}}$ in the lung (Nos. 4, 8 and 14) and 2 animals were positive for $\mathrm{PrP}^{\mathrm{Sc}}$ in the mammary gland (Nos. 11, 12).

\subsection{Location of $\operatorname{PrP}^{\mathrm{Sc}}$ in the lung, mammary gland and lymph nodes of coinfected animals}

Positive reactions to $\operatorname{PrP}^{\mathrm{Sc}}$ were always observed within the germinal center of lymphoid follicles as scattered aggregates (Fig. 1A and 1B) but not all cases with LFH in tissue showing the simultaneous presence of $\operatorname{PrP}^{\mathrm{Sc}}$ (Tab. II). Interestingly, the presence of $\operatorname{PrP}^{\mathrm{Sc}}$ was never observed in other VMV-related lesions such as interstitial inflammation in the lung or mammary gland (Fig. 1C). $\mathrm{PrP}^{\mathrm{Sc}}$ in the regional lymph node was also observed within the germinal center of cortical follicles (Fig. 1D). Finally, $\operatorname{PrP}^{\mathrm{Sc}}$ positive results in the lung or mammary gland were always seen together with $\mathrm{PrP}^{\mathrm{Sc}}$ presence in the corresponding regional lymph nodes (Tab. II) but a positive result in those lymph nodes did not necessarily imply a positive detection in the lung or mammary gland.

\subsection{PRNP genotypes}

A summary of the genotype results is shown in Table III. The 91 animals of this study were genotyped for PRNP and they were included in one of the predefined risk groups [11]. Overall, genotypes from scrapie negative sheep belonged to risk groups from 2, 3, 4 and 5, whereas scrapie positive animals were always included in risk groups 3 and 5. The most frequent genotype was ARQ/ARQ (61 sheep, $67.03 \%$ ), with 46 ewes being scrapie positive and 15 animals scrapie negative.

\section{DISCUSSION}

Scrapie and VM are worldwide ovine diseases with a relative high prevalence in some geographical areas. Scrapie and VM are representative models for diseases caused by prions and lentiviruses, respectively. Whether the presence of one disease affects the time of onset of the other has not yet been fully studied.

Chronic inflammations can lead to $\mathrm{PrP}^{\mathrm{Sc}}$ deposition in the affected organs both in experimental conditions in mice and sheep ${ }^{2}[20,44]$ and in natural infections in sheep [6, 25, 27]. Moreover, the incubation period for TSE decreases if there is a previous or concurrent inflammatory process such as enteritis and encephalitis $[13,48]$. The inflammatory process

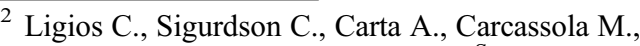
Cancedda M.G., Madau L., et al., $\operatorname{PrP}^{\mathrm{Sc}}$ deposits in lungs and mammary glands in sheep experimentally coinfected with scrapie and maedi-visna virus, Neuroprion 2006, Torino, 2006, p. 261.
} 
that takes place in the gut causes a local upregulation of $\operatorname{PrP}^{\mathrm{C}}$ that favors gut-associated lymphoid tissue invasion by $\mathrm{PrP}^{\mathrm{Sc}}$ and lymphatic dissemination of the scrapie agent [48]. In the $\mathrm{CNS}$, the inflammatory reaction produces activated infected immune cells that infiltrate the tissue and facilitate the process of $\mathrm{PrP}^{\mathrm{Sc}}$ neuroinvasion [13]. Actually, in vitro small-ruminant lentivirus infection in microglial cells enhances $\mathrm{PrP}^{\mathrm{C}}$ conversion to $\mathrm{PrP}^{\mathrm{Sc}}[50]$. The global interpretation of the main results obtained in the present work (Tab. II) indicates that the presence of VMV-related lesions in non-scrapie target organs (lung and mammary gland) can favor $\mathrm{PrP}^{\mathrm{Sc}}$ deposition within the hyperplasic lymphoid follicles induced by the lentivirus. The presence of $\mathrm{PrP}^{\mathrm{Sc}}$ in non-target tissues seems to be preceded by $\mathrm{PrP}^{\mathrm{Sc}}$ deposition in the associated lymph node (mediastinal or mammary) since no case showed $\mathrm{PrP}^{\mathrm{Sc}}$ in the lung and/or the mammary gland without $\mathrm{PrP}^{\mathrm{Sc}}$ in the corresponding lymph node. Likely, both $\operatorname{PrP}^{\mathrm{Sc}}$ lymphoinvasion in the lymph node and VM lesions in the organ must be present for the detection of $\mathrm{PrP}^{\mathrm{Sc}}$ in that organ. The presence of $\mathrm{PrP}^{\mathrm{Sc}}$ in LRS does not have any relevant clinical or pathological features but the lymphoinvasion is usually the previous phase to the neuroinvasion and the appearance of clinical signs [53]. However, lymphoinvasion is not always a prerequisite: in ARQ/ARQ Sarda sheep there is neuroinvasion in preclinical animals with lack of deposition of $\mathrm{PrP}^{\mathrm{Sc}}$ in the LRS [28]. In this work, IHC and WB techniques have been used as reference techniques since they are official confirmation tests for the OIE, whereas ELISA have been used for studying their performance in tissues other than the CNS and LRS. If IHC and/or WB were positive, the animal was classified as positive, independently of the results obtained by the two ELISA used.

In this study, 10 of $13 \mathrm{PrP}^{\mathrm{Sc}}$ positive lungs and mammary glands were positive for VMV by PCR, pointing out the possible role of VMV in up-regulating the PrP conversion [50] or spread in body tissues. PCR positive results may have been underestimated, since, VMV provirus detected by PCR was found only in about half the number of organs with VMV-related lesions. Possibly, the presence of the virus in the VMV-related lesions was not constant, the sample obtained did not contain provirus or the primer sequence was inadequate for a mutated proviral DNA template in the animal tissue under study. VMV proviral sequences may have been detected by PCR in the blood but unfortunately blood was not available from any of the sheep studied.

In scrapie, both the lung and mammary gland are classified as "Lower infectivity tissues" sharing the same category as lymphoreticular organs such as the spleen, tonsil and lymph nodes ${ }^{3}$. Regarding the lung, neither the presence of $\mathrm{PrP} \mathrm{P}^{\mathrm{Sc}}$ nor infectivity has been proven so far. In the mammary gland, $\operatorname{PrP}^{\mathrm{Sc}}$ has been found only when there is a concurrent inflammatory process, but infectivity has not been detected ${ }^{3}$. Here, we demonstrate the presence of $\operatorname{PrP}^{\mathrm{Sc}}$ in the lung with VMV-related lesions. The $\operatorname{PrP}^{\mathrm{Sc}}$ presence in the lung and mammary gland does not seem to have any additional pathological role in these organs but it could modify the epidemiology and/ or transmission of scrapie by increasing infectivity of these tissues and - for the mammary gland - by increasing the possibility of infection of the lambs through scrapie infected colostrum/ milk. Recently, it has been demonstrated that milk from naturally-infected scrapie sheep without mastitis and with no $\mathrm{PrP}^{\mathrm{Sc}}$ in the mammary gland is infective for mice in experimental conditions [25]. Furthermore, $\operatorname{PrP}^{\mathrm{Sc}}$ has been amplified by PMCA in milk from clinically normal scrapie-exposed sheep [31]. Recent work has also shown that lambs fed with milk from experimentally co-infected scrapie-VMV ewes develop scrapie clinical signs faster than lambs fed with milk from only scrapie experimentally-infected sheep, indicating that VMV could play an important role in scrapie transmission ${ }^{4}$.

\footnotetext{
${ }^{3}$ WHO Guidelines on tissue infectivity distribution in transmissible spongiform encephalopathies [on line] (2007) http://www.who.int/biologicals/ BS 2078 TSE.pdf [consulted 20 January 2010].

${ }^{4}$ Ligios C., Cancedda G.M., Carta A., Santucciu C., Maestrale C., Demontis F., et al., Prion infectivity in milk from ARQ/ARQ sheep experimentally infected with scrapie and MAEDI-VISNA virus, Neuroprion 2009, Thessaloniki-Chalkidiki, 2009, p. 118.
} 
Interestingly, we did not find any VMVinduced inflammatory process in the CNS. This finding agrees with previous observations indicating that the nervous form of $\mathrm{VM}$ is almost absent from the Rasa Aragonesa breed ${ }^{5}$ and as a consequence, we can not draw any conclusion about the putative interaction between scrapie and VMV at the CNS level. However, this form is frequently observed in other regions of Spain [4]. This difference may be explained by genetic strain variability, breed genetic background or factors related with the rearing system. There is a report on a single case of concomitant non-suppurative encephalitis and Nor98-like atypical scrapie without $\mathrm{PrP}^{\mathrm{Sc}}$ deposits in the ectopic lymphoproliferative process, which is explained by lymphotropism differences between prion strains [54].

Mean age results show that scrapie-affected sheep either infected or not infected with VM had significantly lower age at the time of death when compared with the non-scrapie-affected sheep. This difference may be related to the genetic make up of scrapie. Moreover, the results between the $\mathrm{Sc}+$ groups show that VM infection or the development of LFH induced by VM do not influence the course of scrapie infection. Additionally, clinical status of scrapie positive animals at the time of death is similar independently from VMV status. To our understanding, these results indicate that neither VMV infection nor the presence of VMVinduced lesions affect the course of scrapie infection. Overall, these observations were in agreement with previous work on experimentally scrapie-VMV coinfected animals, where the clinical evolution of scrapie was independent of VM infection in spite of the development of VMV-related lesions in the lung and mammary gland $^{2}$. In addition, PRNP genotype frequencies among the 91 sheep included in this work were in agreement with those previously-reported in Rasa Aragonesa breed, where scrapie-affected sheep had only genotypes belonging to groups $\mathrm{R} 3, \mathrm{R} 4$ or R5 [1]. The ARQ/ARQ genotype was the most relevant genotype among scrapie affected sheep (75.4\%) as previously described [1]; these results were in agreement with other

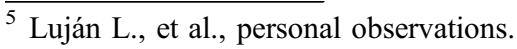

reports indicating that VRQ and ARQ are the most susceptible haplotypes for scrapie infection [3]. Therefore, the presence of VM infection does not seem to influence the specific phenotypes affected by scrapie.

The pathogenesis associated to $\operatorname{PrP}^{\mathrm{Sc}}$ deposition is not completely understood but recruitment of lymphoid cells in the inflamed organs enables prion replication in atypical places by the up-regulation of lymphotoxin- $\alpha$ produced by $\mathrm{B}$ lymphocytes and an ectopic induction of lymphotoxin- $\alpha$ receptor by the FDC-M1+ expressing normal prion protein [20]. Moreover, $\mathrm{PrP}^{\mathrm{C}}$ expression is increased in some inflammatory processes such as inclusion-body myositis, inflammatory myophathies and skin tumoral or inflammatory diseases [37, 43, 55], possibly due to the role of $\operatorname{PrP}^{\mathrm{C}}$ in general stress-response [24]. This increase of $\operatorname{PrP}^{C}$ can favor the extraneural conversion of $\operatorname{PrP}^{\mathrm{C}}$ to $\mathrm{PrP}^{\mathrm{Sc}}$ [23]. Inflammations caused by some viruses like small ruminant lentiviruses, human adenovirus 5 and vesicular stomatitis virus may increase local $\operatorname{PrP}^{\mathrm{C}}$ expression $[7,29,50]$. Altogether, it is reasonable to expect the presence of $\mathrm{PrP}^{\mathrm{Sc}}$ in organs/tissues not previously regarded as targets for scrapie but being targets for other pathogens such as VMV, making the study of VM-scrapie coinfected animals relevant for the understanding of the pathogenesis of both diseases.

Acknowledgements. This work has been funded by a grant of Ministerio de Ciencia e Innovación (ref. AGL2007-66874-C04 GAN). We are indebted to Belén Marín and the technicians at the Research Center on Encephalopaties and Emerging Diseases (University of Zaragoza). We thank Dr Ignacio de Blas for statistical help and we also thank Santiago Becerra and Rosario Puyó for technical help. E. Salazar was a PhD student funded by grant B073/2006 from Gobierno de Aragón.

\section{REFERENCES}

[1] Acín C., Martín-Burriel I., Goldmann W., Lyahyai J., Monzón M., Bolea R., et al., Prion protein gene polymorphisms in healthy and scrapie-affected Spanish sheep, J. Gen. Virol. (2004) 85:2103-2110.

[2] Badiola J.J., Monleón E., Monzón M., Acín C., Luján L., Fernández D., et al., Description of the first cases of BSE in Spain, Vet. Rec. (2002) 151:509-510. 
[3] Baylis M., Chihota C., Stevenson E., Goldmann W., Smith A., Sivam K., et al., Risk of scrapie in British sheep of different prion protein genotype, J. Gen. Virol. (2004) 85:2735-2740.

[4] Benavides J., Gómez N., Gelmetti D., Ferreras M.C., García-Pariente C., Fuertes M., et al., Diagnosis of the nervous form of Maedi-Visna infection with a high frequency in sheep in Castilla y León, Spain, Vet. Rec. (2006) 158:230-235.

[5] Bolea R., Monleón E., Schiller I., Raeber A.J., Acín C., Monzón M., et al., Comparison of immunohistochemistry and two rapid tests for detection of abnormal prion protein in different brain regions of sheep with typical scrapie, J. Vet. Diagn. Invest. (2005) 17:467-469.

[6] Caplazi P., O’Rourke K., Wolf C., Shaw D., Timothy V., Baszler T.V., Biology of $\operatorname{PrP}^{\mathrm{Sc}}$ accumulation in two natural scrapie-infected sheep flocks, J. Vet. Diagn. Invest. (2004) 16:489-496.

[7] Caruso P., Burla R., Piersanti S., Cherubini G., Remoli C., Martina Y., Saggio I., Prion expression is activated by Adenovirus 5 infection and affects the adenoviral cycle in human cells, Virology (2009) 385:343-350.

[8] Cultip R.C., Jackson T.A., Lehmkuhl H.D., Lesions of ovine progressive pneumonia: interstitial pneumonitis and encephalitis, Am. J. Vet. Res. (1979) 40:1370-1374.

[9] Cultip R.C., Lehmkuhl H.D., Wood R.L., Brodgen K.A., Arthritis associated with ovine progressive pneumonia, Am. J. Vet. Res. (1985) 46:65-68.

[10] Cultip R.C., Lehmkuhl H.D., Mastitis associated with ovine progressive pneumonia virus infection in sheep, Am. J. Vet. Res. (1985) 46:326-328.

[11] Dawson M., Hoinville L.J., Hosie B.D., Hunter N., Guidance on the use of PrP genotyping as an aid to the control of clinical scrapie. Scrapie Information Group, Vet. Rec. (1998) 142:623-625.

[12] Forsman A., Weiss R.A., Why is HIV a pathogen?, Trends Microbiol. (2008) 16:555-560.

[13] Friedman-Levi Y., Ovadia H., Hoftberger R. Einstein O., Abramsky O., Budka H., Gabizon R., Fatal neurological disease in scrapie-infected mice induced for experimental autoimmune encephalomyelitis, J. Virol. (2007) 31:9942-9949.

[14] García de Jalón J.A., De las Heras M., Balaguer L., Badiola J.J., Enfermedad del prurigo lumbar (scrapie) en la oveja: Diagnóstico en 5 rebaños, Med. Vet. (1987) 4 : $5-6$.

[15] González L., Badiola J.J., Gelabert J.L., Neumonía progresiva (MAEDI) en el ganado ovino del País Vasco, Med. Vet. (1984) 1:277-282.

[16] González L., Dagleish M.P., Bellworthy S.J., Siso S., Stack M.J., Chaplin M.J., et al., Postmortem diagnosis of preclinical and clinical scrapie in sheep by the detection of disease-associated PrP in their rectal mucosa, Vet. Rec. (2006) 158:325-331.
[17] Gudnadottir M., Visna-Maedi in sheep, Progr. Med. Virol. (1974) 18:336-349.

[18] Hadlow G., To a better understanding of natural scrapie, in: Bradley R., Savey M., Marchant B. (Eds.), Subacute Spongiform encephalopathies, Kluwer Academic Publishers, Boston, 1961, pp. 117-130.

[19] Hadlow W.J., Kennedy R.C., Race R.E., Natural infection of Suffolk sheep with scrapie virus, J. Infect. Dis. (1982) 146:657-664.

[20] Heikenwalder M., Zeller N., Seeger H., Prinz M., Klöhn P.C., Schwarz P., et al., Chronic lymphocytic inflammation specifies the organ tropism of prions, Science (2005) 307:1107.

[21] Horiuchi M., Yamazaki N., Ikeda T., Ishiguro N., Shinagawa M., A cellular form of prion protein $\left(\operatorname{PrP}^{C}\right)$ exists in many nonneuronal tissues of sheep, J. Gen. Virol. (1995) 76:2583-2587.

[22] Ikegami Y., Ito M., Isomura H., Momotani E., Sasaki K., Muramatsu Y., et al., Pre-clinical and clinical diagnosis of scrapie by detection of PrP protein in tissues of sheep, Vet. Rec. (1991) 128:271-275.

[23] Kovács G.G., Lindeck-Pozza E., Chimelli L., Araújo A.Q.C., Gabbai A.A., Strobel T., et al., Creutzfeldt-Jakob disease and inclusion body myositis: abundant disease-associated prion protein in muscle, Ann. Neurol. (2004) 55:121-125.

[24] Kovács G.G., Kalev O., Gelpi E., Haberler C., Wanschitz J., Strohschneider M., et al., The prion protein in human neuromuscular diseases, J. Pathol. (2004) 204:241-247.

[25] Lacroux C., Simon S., Benestad S.L., Maillet S., Mathey J., Lugan S., et al., Prions in milk from ewes incubating natural scrapie, PloS Pathog. (2008) 4:e1000238.

[26] Langeveld J.P.M., Jacobs J.G., Erkens J.H.F., Bossers A., van Zijderveld F.G., van Keulen L.J.M., Rapid and discriminatory diagnosis of scrapie and BSE in retro-pharyngeal lymph nodes of sheep, BMC Vet. Res. (2006) 2:19.

[27] Ligios C., Sigurdson C.J., Santucciu C., Carcassola G., Manco G., Basagni M., et al., $\operatorname{PrP}^{\mathrm{Sc}}$ in mammary glands of sheep affected by scrapie and mastitis, Nat. Med. (2005) 11:1137-1138.

[28] Ligios C., Cancedda M.G., Madau L., Santucciu C., Maestrale C., Agrimi U., et al., $\operatorname{PrP}(\mathrm{Sc})$ deposition in nervous tissues without lymphoid tissue involvement is frequently found in ARQ/ARQ Sarda breed sheep preclinically affected with natural scrapie, Arch. Virol. (2006) 151:2007-2020.

[29] Lötscher M., Recher M., Hunziker L., Klein M.A., Immunologically induced, complement-dependent upregulation of the prion protein in the mouse spleen: follicular dendritic cells versus capsule and trabeculae, J. Immunol. (2003) 170:6040-6047.

[30] Luján L., García-Marín J.F., Fernández de Luco D., Vargas A., Badiola J.J., Pathological changes in the lungs and mammary glands of sheep and relationship with maedi-visna infection, Vet. Rec. (1991) 129:51-54 
[31] Maddison B.C., Baker C.A., Rees H.C., Terry L.A., Thorne L., Bellworthy S.J., et al., Prions are secreted in milk from clinically normal scrapie-exposed sheep, J. Virol. (2009) 83:8283-8286.

[32] Monleón E., Monzón M., Hortells P., Vargas A., Acín C., Badiola J.J., Detection of $\operatorname{PrP}^{\mathrm{Sc}}$ on lymphoid tissues from naturally affected scrapie animals: comparison of three visualization systems, J. Histochem. Cytochem. (2004) 52:145-151.

[33] Moudjou M., Frobert Y., Grassi J., La Bonnardière C., Cellular prion protein status in sheep: tissue-specific biochemical signatures, J. Gen. Virol. (2001) 82:20172024.

[34] Narayan O., Clements J.E., Biology and pathogenesis of lentiviruses, J. Gen. Virol. (1989) 70:1617-1639.

[35] Oliver R.E., Gorham J.R., Parish S.F., Hadlow W.J., Naravan O., Ovine progressive pneumonia: pathologic and virologic studies on the naturally occurring disease, Am. J. Vet. Res. (1981) 42:1554-1559.

[36] O’Rourke K.I., Baszler T.V., Parish S.M., Knowles D.P., Preclinical detection of $\mathrm{PrP}^{\mathrm{Sc}}$ in nictitating membrane lymphoid tissue of sheep, Vet. Rec. (1998) 142:489-491.

[37] Pammer J., Weninger W., Tschachler E., Human keratinocytes express cellular prion-related protein in vitro and during inflammatory skin diseases, Am. J. Pathol. (1998) 153:1353-1358.

[38] Pérez M., Biescas E., de Andrés X., Leginagoikoa I., Salazar E., Berriatua E., et al., Visna/maedi virus serology in sheep: survey, risk factors and implementation of a successful control programme in Aragón, Vet. J. (2009) doi:10.1016/j.tvj1.2009.07.031.

[39] Prusiner S.B., Novel proteinaceous infectious particles cause scrapie, Science (1982) 216:136-144.

[40] Reina R., Mora M.I., Glaria I., García I., Solano C., Luján L., et al., Molecular characterization and phylogenetic study of Maedi Visna and Caprine Arthritis Encephalitis viral sequences in sheep and goats from Spain, Virus Res. (2006) 121:189-198.

[41] Rubenstein R., Merz P.A., Kascsak R.J., Carp R.I., Scalici C.L., Fama C.L., Wisniewski H.M., Detection scrapie-associated fibrils (SAF) and SAF proteins from scrapie-affected sheep, J. Infect. Dis. (1987) 156:36-42.

[42] Saman E., van Eynde G., Luján L., Extramiana B., Harkiss G., Tolari F., et al., A new sensitive serological assay for detection of lentivirus infections in small ruminants, Clin. Diagn. Lab. Immunol. (1999) 6:734-740.

[43] Sarkozi E., Askanas V., Engel W.K., Abnormal accumulation of prion protein mRNA in muscle fibers of patients with sporadic inclusion-body myositis and hereditary inclusion-body myopathy, Am. J. Pathol. (1994) 145:1280-1284.
[44] Seeger H., Heikenwalder M., Zeller N., Kranich J., Schwarz P., Gaspert A., et al., Coincident scrapie infection and nephritis lead to urinary prion excretion, Science (2005) 310:324-326.

[45] Sigurdsson B., Grimsson H., Palsson P.A., Maedi, a chronic progressive infection of sheep's lungs, J. Infect. Dis. (1952) 90:233-241.

[46] Sigurdsson B., Rida, a chronic encephalitis of sheep with general remarks on infections which develop slowly and some of their special characteristics, Br. Vet. J. (1954) 110:341-354.

[47] Sigurdsson B., Palsson P.A., Grimsson H., Pathology of Visna. Transmissible demyelinating disease in sheep in Iceland, Acta Neuropathol. (1962) 1:343-362.

[48] Sigurdson C.J., Heikenwalder M., Manco G., Barthel M., Schwarz P., Stecher B., et al., Bacterial colitis increases susceptibility to oral prion disease, J. Infect. Dis. (2009) 199:243-252.

[49] Spraker T.R., VerCauteren K.C., Gidlewski T., Schneider D.A., Munger R., Balachandran A., O'Rourke K.I., Antemortem detection of PrPCWD in preclinical, ranch-raised Rocky Mountain elk (Cervus elaphus nelsoni) by biopsy of the rectal mucosa, J. Vet. Diagn. Invest. (2009) 21:15-24.

[50] Stanton J.B., Knowles D.P., O'Rourke K.I., Herrmann-Hoesing L.M., Mathison B.A., Baszlen T.V., Small-Ruminant Lentivirus enhances $\operatorname{PrP}^{\mathrm{Sc}}$ accumulation in cultured sheep microglial cells, J. Virol. (2008) 82:9839-9847.

[51] Vargas F., Bolea R., Monleón E., Acín C., Vargas A., De Blas I., et al., Clinical characterisation of natural scrapie in a native Spanish breed of sheep, Vet. Rec. (2005) 156:318-320.

[52] Vargas F., Luján L., Bolea R., Monleón E., MartínBurriel I., Fernández A., et al., Detection and clinical evolution of scrapie in sheep by 3rd eyelid biopsy, J. Vet. Intern. Med. (2006) 20:187-193.

[53] Van Keulen L.J., Vromans M.E., van Zijderveld F.G., Early and late pathogenesis of natural scrapie infection in sheep, APMIS (2002) 110:23-32.

[54] Vidal E., Tortosa R., Costa C., Benavides J., Francino O., Sánchez-Robert E., et al., Lack of $\operatorname{PrP}^{\mathrm{Sc}}$ immunostaining in intracranial ectopic lymphoid follicles in a sheep with concomitant non-suppurative encephalitis and Nor98-like atypical scrapie: a case report, Vet. J. (2008) 177:283-288.

[55] Zanusso G., Vattemi G., Ferrari S., Tabaton M., Pecini E., Cavallaro T., et al., Increased expression of the normal cellular isoform of prion protein in inclusion-body myositis, inflammatory myopathies and denervation atrophy, Brain Pathol. (2001) 11:182-189. 